UDC 633.491-18

Original research paper

doi:10.5937/AASer1845101B

Acta Agriculturae Serbica, Vol. XXIII, 45 (2018); 101-110

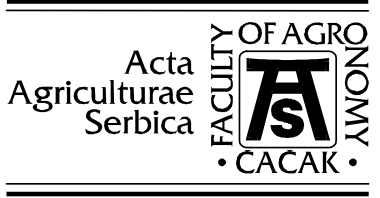

\title{
Effect of different rates and methods of application of NPK-fertilizers on the quality of potato tubers
}

\author{
Ljiljana Bošković-Rakočević ${ }^{1}$, Zoran Dinić ${ }^{2}$, Goran Dugalić ${ }^{1}$, \\ Marijana Dugalić ${ }^{1}$, Jelena Mladenović ${ }^{1}$, Milena Đurić ${ }^{1}$ \\ ${ }^{I}$ University of Kragujevac, Faculty of Agronomy, Cara Dusana 34, 32000 Čačak, \\ Serbia \\ ${ }^{2}$ Institute for Soil Science, Teodora Drajzera 6, 11000 Belgrade, Serbia
}

Corresponding author: 1jiljabr@kg.ac.rs

\begin{abstract}
Research on the effect of different rates and methods of application of mineral NPK fertilizers on the quality of potato variety 'Carrera' was conducted on a luvisol of the Radočelo Mountain massif. Treatments included an unfertilized control, NPK 16:16:16 (1500 kg/ha) applied in-furrow at planting, NPK 16:16:16 (1200 kg/ha) applied in-furrow at planting, and NPK 16:16:16 applied at $700 \mathrm{~kg} /$ ha during seedbed preparation and at $500 \mathrm{~kg} / \mathrm{ha}$ in-furrow at planting. Results on the nutritional value of potato tubers showed that the levels of tested nutrients were higher in the skin than in the flesh. The concentrations of tested nutrients in potato tubers were highest at the highest NPK fertilizer rate, whereas the lowest levels of all nutrients, except Fe, were determined in tubers at NPK rates of $700 \mathrm{~kg} / \mathrm{ha}$ applied pre-plant and $500 \mathrm{~kg} / \mathrm{ha}$ applied at planting.
\end{abstract}

Keywords: potato, NPK fertilizers, tuber quality.

\section{Introduction}

In order to achieve high, stable and quality yields, the potato plant requires the presence of all macro (N, P, K, Ca, Mg, S) and microelements (Fe, Mn, B, $\mathrm{Zn}, \mathrm{Cu}, \mathrm{Mo}$ ), which must be in optimal amounts. The importance of nitrogen primarily lies in the fact that it is a constituent element of proteins, and it 
influences the development of numerous physiological and biochemical processes, plant growth, the formation of organs, and therefore it affects the structure and quality of yield. Phosphorus accelerates tuber growth, increases the quality of tubers (they contain more starch), reduces the scum of tubers. Potassium has an important role in the physiological processes of the plant, improves the quality of cooking and processing, increases the resistance of tubers to injuries and affects the concentration of dry matter. Due to potassium deficiency, it is difficult to keep the tubers, which are then more susceptible to the formation of dark spots. Microelements are included as catalysts in numerous metabolic and physiological processes in plants. Iron is an essential microelement involved in the complex oxidation reaction of ferro-chlorogenic acid during the cooking of potatoes, and the presence of which may cause darkening, which is undesirable; therefore, the optimum amount of this element is necessary in order to avoid this phenomenon. Manganese has a positive effect on the resistance to diseases of potatoes, the synthesis of organic substances, better utilization of the nitrate and ammonium forms of nitrogen. Zinc is a component of many enzymatic systems, and it plays an important role as an ingredient of the hormone auxin. Copper influences the transfer of sugar from the above-ground parts of plants to the tubers, and thus enhances the synthesis and storage of starch in the tubers (Gvozden, 2016).

Excessive amounts of fertilizers can negatively affect not only tuber yield but also tuber quality. Bugarčić (2000) concluded that high rates, above $1500 \mathrm{~kg} / \mathrm{ha}$, can negatively affect the productive and technological characteristics of potato tubers. Hajšlova et al. (2005) found that the amount of nitrogen used is negatively correlated with the content of dry matter and starch. Also, nitrogen over-fertilization can cause an increase in nitrogen content in tubers relative to potassium content, thus increasing the susceptibility of tubers to after-cooking darkening, as well as a decline in their nutritional value (Rengel and Damon, 2008).

The use of mineral fertilizers, together with other sources of soil contamination, may lead to the occurrence a high concentration of harmful and hazardous substances in the soil. These substances are adopted by plants and included in the plant-human diet chain (Zhuang et al., 2009; BoškovićRakočević et al., 2014). In potato tubers, a high content of nitrate nitrogen usually comes from harmful substances (Bošković-Rakočević and Pavlović, 2009). Due to the presence of cadmium in crude phosphates, hazardous materials, used as raw material for the production of phosphorus fertilizers, can cause an increase in cadmium content in potato tubers (McLaughlin et al., 1999; Pavlović $i$ sar., 2014). The presence of other heavy metals is mainly due to their high content in the parent material, the atmosphere, irrigation water, exhaust gases, etc. (Al-Khashman, 2004; Wei and Yang, 2010). 


\section{Materials and methods}

The effect of different rates of mineral fertilizers on the yield and quality of 'Carrera' potatoes was examined in 2015. The experiment was laid out in a randomized block design with three replications at the village of Bzovik, Municipality of Kraljevo (Latitude $43^{0} 25^{\prime} 33^{\prime \prime}$ N, Longitude $20^{\circ} 25^{\prime} 53^{\prime \prime}$ E; 1107 $m$ altitude), on a luvisol of the Radočelo Mountain massif.

The experiment included the following treatments: 1. T1 - Control (without fertilization); 2. NPK 16:16:16 (1500 $\mathrm{kg} / \mathrm{ha})$ applied in-furrow at planting, 3 . NPK 16:16:16 (1200 kg/ha) applied in-furrow at planting, 4. NPK 16:16:16 applied at $700 \mathrm{~kg} / \mathrm{ha}$ during seedbed preparation and at $500 \mathrm{~kg} / \mathrm{ha}$ in-furrow at planting. During seedbed preparation, immediately before planting on 29 April $2015,700 \mathrm{~kg} / \mathrm{ha}$ NPK-fertilizers was applied in treatment T4. During planting, on April 30, planned rates of mineral fertilizers were applied to open furrows. Plot size was $23.275 \mathrm{~m}^{2}(4.9 \mathrm{~m} \times 4.75 \mathrm{~m})$.

Before trial establishment, soil samples were collected from a depth of $30 \mathrm{~cm}$ for the following analyses: soil $\mathrm{pH}$ was measured at a 1:2.5 ratio of soil to distilled water and $1 \mathrm{M} \mathrm{KCl}$; humus content was determined by oxidation with $\mathrm{KMnO}_{4}$ solution (according to Kotzman); total nitrogen was estimated by Kjeldahl analysis (Gerhardt Vapodest); available phosphorus and potassium were evaluated by extraction with $0.1 \mathrm{M} \mathrm{NH}_{4}$-lactate and $0.4 \mathrm{M} \mathrm{CH}_{3} \mathrm{COOH}$, according to Egner-Riehm ( $\mathrm{P}$ was analyzed spectrophotometrically by the phosphovanadate colorimetric method and $\mathrm{K}$ was determined by flame photometry); available $\mathrm{Al}$ was measured by Sokolov's method. Available $\mathrm{Cu}, \mathrm{Fe}, \mathrm{Zn}, \mathrm{Mn}, \mathrm{Pb}$ and $\mathrm{Ni}$ were determined by extraction with $0.005 \mathrm{M}$ DTPA $+0.01 \mathrm{M} \mathrm{CaCl}_{2}+$ $0.1 \mathrm{M}$ TEA solution, $\mathrm{pH}=7.3$ (Lindsay and Norvell, 1978), and analyzed using atomic absorption spectroscopy.

After harvesting, potato tubers were sampled for determining the nutritional value (levels of major macro- and micronutrients) and the content of some harmful substances in the skin and the flesh. Nitrogen content was determined by elemental analysis using a Vario EL III Elemental Analyzer; the levels of K, Fe, $\mathrm{Mn}, \mathrm{Cu}, \mathrm{Zn}, \mathrm{Pb}, \mathrm{Ni}$ and $\mathrm{Al}$ were assessed by digestion in concentrated $\mathrm{HNO}_{3}$ and $30 \% \mathrm{H}_{2} \mathrm{O}_{2}$, with $\mathrm{K}$ readings made by a flame photometer and measurements of the other elements taken by an ICP.

\section{Results and disscusion}

Mean air temperature datafor Kraljevo for the growing season of potatoes in 2015 show that temperatures during potato germination were within the optimal range of values (Table 1). However, in July, especially during the last ten days, the average temperature $\left(25.3^{\circ} \mathrm{C}\right)$ exceeded the optimal value $\left(21-25^{\circ} \mathrm{C}\right)$, which reduced tuber bulking. According to the results of Bugarčić (2000), temperatures above $25^{\circ} \mathrm{C}$ significantly reduced tuber bulking. 
Table 1. Mean air temperatures $\left({ }^{\circ} \mathrm{C}\right)$ over ten-day periods and months and sum of precipitation $(\mathrm{mm})$ for the area of Kraljevo during the growing season of potatoes in 2015

\begin{tabular}{|l|c|c|c|c|c|c|c|c|}
\hline \multirow{3}{*}{ Months } & \multicolumn{4}{|c|}{ Temperature $\left({ }^{\circ} \mathrm{C}\right)$} & \multicolumn{4}{c|}{ Sum of precipitation (mm) } \\
\cline { 2 - 4 } & \multicolumn{3}{|c|}{ Ten-day period } & \multirow{2}{*}{ Mean } & \multicolumn{3}{c|}{ Ten-day period } & \multirow{2}{*}{ Total } \\
\cline { 2 - 6 } & I & II & III & & I & II & III & \\
\hline April & 7.1 & 13.5 & 14.2 & 11.6 & 48.2 & 16.4 & 2.0 & 66.6 \\
\hline May & 18.2 & 18.2 & 16.3 & 17.6 & 7.8 & 35.0 & 47.7 & 90.5 \\
\hline June & 20.4 & 21.4 & 17.8 & 19.9 & 17.0 & 39.2 & 31.8 & 88.0 \\
\hline July & 23.1 & 24.2 & 25.3 & 24.2 & 1.2 & 2.2 & 5.0 & 8.4 \\
\hline August & 25.2 & 25.6 & 22.4 & 24.4 & 7.3 & 27.3 & 2.1 & 36.7 \\
\hline September & 23.2 & 19.0 & 16.3 & 19.5 & 15.2 & 30.8 & 38.3 & 84.3 \\
\hline
\end{tabular}

During the growing season in 2015, there was a considerable deficit of rainfall, especially in July and August (Table 1). During germination and potato tuber set, there was enough moisture in the soil, which had a positive effect on potato tuber set. In July, there was only $8.4 \mathrm{~mm}$ rainfall precipitation (25 days without precipitation), while in August it was $36.7 \mathrm{~mm}$.

The results of agrochemical testing (Table 2) showed a strongly acid reaction of the soil, and high contents of total nitrogen, available phosphorus and potassium in the soil. The humus content was medium. Regardless of the strongly acid reaction of this soil, mobile aluminum content $(3.38 \mathrm{mg} / 100 \mathrm{~g}$ soil) was within the limits tolerable to plants (Jakovljević et al., 1991), which is of high importance given the particularly deleterious effect of excess mobile aluminum in the arable layer as evidenced by the decrease in root penetration depth and, hence, reduction in the uptake of nutrients and water from the soil (Foy, 1974).

Table 2. Agrochemical characteristics of the soil

\begin{tabular}{|c|c|c|c|c|c|c|c|c|c|}
\hline \multirow{2}{*}{$\begin{array}{c}\text { Depth } \\
(\mathrm{cm})\end{array}$} & \multicolumn{2}{|c|}{$\mathrm{pH}$} & Humus & $\mathrm{N}$ & $\mathrm{P}_{2} \mathrm{O}_{5}$ & $\mathrm{~K}_{2} \mathrm{O}$ & $\mathrm{Ca}$ & $\mathrm{Mg}$ & $\mathrm{Al}$ \\
\cline { 2 - 7 } & $\mathrm{H}_{2} \mathrm{O}$ & $\mathrm{KCl}$ & $(\%)$ & $(\%)$ & \multicolumn{5}{c|}{$\mathrm{mg} / 100 \mathrm{~g}$} \\
\hline $0-30$ & 4.75 & 3.80 & 3.1 & 0.21 & 23.26 & 47.27 & 128.52 & 13.27 & 3.38 \\
\hline
\end{tabular}

The content of available $\mathrm{Zn}(1.52 \mathrm{mg} / \mathrm{kg})$ was medium, the levels of of DTPA-Fe $(55.6 \mathrm{mg} / \mathrm{kg})$ and DTPA-Mn $(61.5 \mathrm{mg} / \mathrm{kg})$ were high, while the content of available $\mathrm{Cu}(0.64 \mathrm{mg} / \mathrm{kg})$ was within the low limits (Ankerman, 1977), (Table 3). The high content of available Fe and Mn was expected, considering the stongly acid reaction of the soil. The content of available forms of $\mathrm{Pb}$ and $\mathrm{Ni}$ was within the maximum permissible concentration range. 
Table 3. Content of available forms of microelements and heavy metals in soil

\begin{tabular}{|c|c|c|c|c|c|c|}
\hline \multirow{2}{*}{$\begin{array}{c}\text { Depth } \\
(\mathrm{cm})\end{array}$} & $\mathrm{Cu}$ & $\mathrm{Fe}$ & $\mathrm{Mn}$ & $\mathrm{Zn}$ & $\mathrm{Pb}$ & $\mathrm{Ni}$ \\
\cline { 2 - 7 } & \multicolumn{6}{|c|}{$\mathrm{mg} / \mathrm{kg}$} \\
\hline $0-30$ & 0.64 & 55.6 & 61.5 & 1.52 & 5.23 & 1.41 \\
\hline
\end{tabular}

Results on the nutritional value of potato tubers showed that the levels of tested nutrients were higher in the skin than in the flesh (Table 4). The content of nitrogen in the flesh of the tuber was in the range of $1.89 \%$ (treatment with NPK 16:16:16 $700 \mathrm{~kg} /$ ha during seedbed preparation and $500 \mathrm{~kg} / \mathrm{ha}$ in-furrow during planting) to $2.16 \%$ (NPK 16:16: $161500 \mathrm{~kg} / \mathrm{ha}$ applied during planting). In the skin, the content of nitrogen varied from 2.42 to $2.61 \%$ in the same treatments. The content of potassium showed a similar tendency of variation in treatments (flesh $2.16-2.34 \%$, skin 3.70-4.02\%), as well as nitrogen. The nitrogen content in the flesh was slightly higher than the average values of $1.56 \%$ (Bártova et al., 2013) and 1.49-1.80\% (Rostami et al., 2015), whereas the level of $\mathrm{K}$ was somewhat lower than the range of 2.6-3.6\% (Trehan and Sharma, 2002). These findings were particularly evidenced in treatments with $1500 \mathrm{~kg} / \mathrm{ha}$ NPK fertilizer, in support of the reports by Rengel and Damon (2008), who found that excessive nitrogen can increase nitrogen content in tubers relative to potassium.

Table 4. Nutritional value of potato tubers

\begin{tabular}{|c|c|c|c|c|c|c|c|}
\hline \multirow{2}{*}{\multicolumn{2}{|c|}{$\begin{array}{c}\text { Fertilization } \\
\text { treatments }\end{array}$}} & $\mathrm{N}$ & $\mathrm{K}$ & $\mathrm{Cu}$ & $\mathrm{Fe}$ & $\mathrm{Mn}$ & $\mathrm{Zn}$ \\
\hline & & \multicolumn{2}{|c|}{$\%$} & \multicolumn{4}{|c|}{$\mathrm{mg} / \mathrm{kg}$} \\
\hline \multirow[t]{3}{*}{ Skin } & $\mathrm{T} 2$ & 2.61 & 4.02 & 9.04 & 98.78 & 87.43 & 36.88 \\
\hline & T3 & 2.48 & 3.70 & 9.32 & 117.55 & 71.58 & 23.38 \\
\hline & $\mathrm{T} 4$ & 2.42 & 3.72 & 6.50 & 158.07 & 50.85 & 25.37 \\
\hline \multirow[t]{3}{*}{ Flesh } & T2 & 2.16 & 2.34 & 5.48 & 28.56 & 17.03 & 20.09 \\
\hline & T3 & 2.00 & 2.29 & 5.43 & 21.82 & 16.20 & 16.98 \\
\hline & T4 & 1.89 & 2.16 & 3.26 & 23.85 & 10.26 & 16.00 \\
\hline
\end{tabular}

*T2-1500 kg ha ${ }^{-1}$ applied in-furrow at planting, T3-1200 kg ha ${ }^{-1}$ applied in-furrow at planting and T4 - applied at $700 \mathrm{~kg} \mathrm{ha}^{-1}$ during seedbed preparation and $500 \mathrm{~kg} \mathrm{ha}^{-1} \mathrm{in}$ furrow at planting

Iron is an essential microelement involved in the complex oxidation reaction of ferro-chlorogenic acid during the cooking of potatoes. Deficiency of Fe is the reason underlying after-cooking darkening as an adverse side-effect of heat treatment; therefore, its content in the tuber should be within the average values (21-58 mg/kg, Kabata-Pendias, 2011). In the present experiment, the content of Fe was higher in the skin of the tuber (skin $98.78-158.07 \mathrm{mg} / \mathrm{kg}$; flesh 21.82-28.56 $\mathrm{mg} / \mathrm{kg}$ ), whereas the lowest content was determined in the treatment with 1200 
$\mathrm{kg} /$ ha of NPK fertilizer applied once, in-furrow at planting. The highest content of Fe was found at the highest application rate of NPK fertilizer.

The results on the content of copper in potato tubers indicated that a higher content of this nutrient was found in the skin $(6.50-9.32 \mathrm{mg} / \mathrm{kg})$ compared to the flesh $(3.26-5.48 \mathrm{mg} / \mathrm{kg})$. The highest content was obtained in the treatment with $1500 \mathrm{~kg} / \mathrm{ha}$ of NPK fertilizers applied in-furrow at planting. However, the content of $\mathrm{Cu}$ in the flesh was within the average values $(3.0-6.6 \mathrm{mg} / \mathrm{kg}$; Kabata-Pendias, 2011) in all treatments.

As with the previously analyzed micronutrients, the content of zinc was within the average values (10-26 mg/kg; Kabata-Pendias, 2011), which is very important in view of the fact that zinc participates in the production of many enzymatic systems (Gvozden, 2016). A higher content of $\mathrm{Zn}$ was determined in the skin compared to the flesh $(23.38-36.88 \mathrm{mg} / \mathrm{kg}, 16.00-20.09 \mathrm{mg} / \mathrm{kg}$, respectively).

The content of $\mathrm{Mn}$ in the skin of potato tubers ranged from 50.85 to 87.43 $\mathrm{mg} / \mathrm{kg}$, while its levels in the flesh were $10.26-17.03 \mathrm{mg} / \mathrm{kg}$, with the highest content in treatment with $1500 \mathrm{~kg} / \mathrm{ha}$ of NPK fertilizers applied in-furrow at planting.

As already stated, the contents of $\mathrm{Cu}, \mathrm{Fe}, \mathrm{Zn}$, and $\mathrm{Mn}$ in the flesh of the tubers were within the range of average values indicated by Kabata-Pendias (2011), but the contents of these elements were slightly higher than the results obtained by Bártova et al. (2013).

In terms of safe food production, it is very important to determine the content of harmful substances, primarily heavy metals in agricultural products, as this is their most common way of entering the plant-human nutrition chain (Zhuang et al., 2009; Bošković-Rakočević et al., 2014). The major problem in growing potatoes on acid soils can be caused by the increased content of aluminum, which significantly reduces yields (Bošković-Rakočević and Bokan, 2003). Also, it can be accumulated in the tubers. The obtained results (Table 5) showed that A1 accumulated in the skin of tuber $(138.42-295.57 \mathrm{mg} / \mathrm{kg}$ ), while the content of Al in the flesh was insignificant $(4.58-12.89 \mathrm{mg} / \mathrm{kg}$ ), and was below the average values (76 mg/kg; Kabata-Pendias, 2011).

Table 5. The content of harmful substances in the potato tuber

\begin{tabular}{|c|c|c|c|c|c|}
\hline \multirow{2}{*}{ Fertilization treatments } & $\mathrm{Al}$ & $\mathrm{Pb}$ & $\mathrm{Cd}$ & $\mathrm{Ni}$ \\
\cline { 2 - 6 } & & \multicolumn{4}{|c|}{$\mathrm{mg} / \mathrm{kg}$} \\
\hline \multirow{3}{*}{ Skin } & $\mathrm{T} 2$ & 138.42 & 0.37 & 0.27 & 2.74 \\
\cline { 2 - 6 } & $\mathrm{T} 3$ & 225.35 & 0.58 & 0.18 & 5.34 \\
\cline { 2 - 6 } & $\mathrm{T} 4$ & 295.57 & 0.61 & 0.25 & 4.78 \\
\hline \multirow{3}{*}{ Flesh } & $\mathrm{T} 2$ & 4.58 & bld & bld & 1.38 \\
\cline { 2 - 6 } & $\mathrm{T} 3$ & 5.67 & bld & bld & 2.47 \\
\cline { 2 - 6 } & $\mathrm{T} 4$ & 12.89 & bld & bld & 2.68 \\
\hline
\end{tabular}

bld-below the limit of detection 
The contents of $\mathrm{Pb}$ and $\mathrm{Cd}$ in the flesh of the potato tubers were below the limit of detection (Table 5), while the content of $\mathrm{Ni}(1.38-2.68 \mathrm{mg} / \mathrm{kg}$ ) was significantly below the toxic concentrations (>10 mg/kg; Kabata-Pendias, 2011). All tested heavy metals were detected in the skin of the tuber, but these values were also low, indicating that potatoes have developed mechanisms at the root that prevent the translocation of heavy metals from the root into edible parts. This mechanism for the sequestration of certain heavy metals $(\mathrm{Cd}, \mathrm{Cu}$ and $\mathrm{Zn})$ is made possible through sulphur-containing proteins which bind these metals to create metabolically inactive complexes that accumulate in vacuoles within the cells. Thus, these elements are excluded from the translocation process. Characteristically, Mn forms complexes with malate in the cytoplasm through which $\mathrm{Mn}$ is transported to the vacuole, where it dissociates from malate and complexes with oxalate as the "terminal acceptor" (Memon et al., 2001). In Pb, this mechanism is based on the formation of $\mathrm{Pb}$-lignin complexes in roots (KrishnaRaj et al., 2000).

As indicated by the analysis of the effect of different rates and methods of application of NPK fertilizer on tuber quality, the highest levels of all tested nutrients were obtained at the highest rate $(1500 \mathrm{~kg} / \mathrm{ha})$, as opposed to the lowest levels of all nutrients, except Fe, under NPK treatment at $700 \mathrm{~kg} /$ ha applied preplant and $500 \mathrm{~kg} / \mathrm{ha}$ applied at planting, with all values being within the optimal range.

\section{Conclusion}

The soil was strongly acid reaction $(\mathrm{pH} / \mathrm{KCl} 3.80)$, with a high content of total nitrogen $(0.21 \%)$, available phosphorus $(23.26 \mathrm{mg} / 100 \mathrm{~g})$ and potassium (47.27 $\mathrm{mg} / 100 \mathrm{~g})$. The humus content was medium $(3.10 \%)$. The content of available $\mathrm{Zn}$ $(1.52 \mathrm{mg} / \mathrm{kg})$ was medium, the levels of DTPA-Fe $(55.6 \mathrm{mg} / \mathrm{kg})$ and DTPA-Mn $(61.5 \mathrm{mg} / \mathrm{kg})$ were high, while the content of available $\mathrm{Cu}(0.64 \mathrm{mg} / \mathrm{kg})$ was within the low limits. The content of available forms of $\mathrm{Pb}$ and $\mathrm{Ni}$ was within the maximum permissible concentration range. Results on the nutritional value of potato tubers showed that the levels of tested nutrients were higher in the skin than in the flesh. The highest levels of all tested nutrients were obtained at the highest rate $(1500 \mathrm{~kg} / \mathrm{ha})$, as opposed to the lowest levels of all nutrients, except Fe, under NPK treatment at $700 \mathrm{~kg} /$ ha applied pre-plant and $500 \mathrm{~kg} / \mathrm{ha}$ applied at planting, with all values being within the optimal range.

\section{Acknowledgements}

This study is part of the TR 31059 project financially supported by the Ministry of Education and Science of the Republic of Serbia. 


\section{References}

Al-Khashman O.A. (2004). Heavy metal distribution in dust, street dust and soils from the work place in Karak Industrial Estate, Jordan. Atmospheric Environment, 38: 6803-6812.

Ankerman R.L. (1977): Soil and Plant Analysis. Soil Science America, 21: 34-45.

Bártová V., Bárta J., Diviš J., Švajner J., Peterka J. (2009): Crude protein content in tubers of starch processing potato cultivars in dependence on different agroecological conditions. Journal of Central European Agriculture, 10 (1): 57-66.

Бошковић-Ракочевић Љ., Бокан Н (2003): Гајење кромпира на земљишту са високим садржајем мобилног алуминијума. Агрознање, 4: 152-160.

Бошковић-Ракочевић, Љ., Павловић, Р. (2009): Утицај азота на принос и садржај нитрата код младог кромпира у пластеничкој производњи. Acta agriculturae Serbica, 14 (27): 93-99.

Bošković Rakočević LJ., Milivojević J., Milošević T., Paunović G. 2014. Heavy metal content of soils and plum orchards in an uncontaminated area. Water Air Soil Pollution, 225: 2199.

Бугарчић Ж. (2000): Кромпир - технологија производње, складиштење и заштита. Београд.

Foy C.D. (1974): Aluminum Toxicity in Plants. Agronomy Journal, 66: 715-719.

Gvozden G. (2016): Ispitivanje uticaja konvencionalnog, integralnog i organskog sistema gajenja na produktivnost, kvalitet i biološku vrednost krompira. Doktorska disertacija, Poljoprivredni fakultet Zemun: 1-212.

Hajšlova J., Schulzova V., Slanina P., Janne K., Hellenäs K. E., Andersson C. (2005): Quality of organically and conventionally grown potatoes: Four-year study of micronutrients, metals, secondary metabolites, enzymic browning and organoleptic properties. Food additives and contaminants, 22 (6): 514-534.

Jakovljević M., Mišović M., Broćić Z. (1991): Uticaj primene organskih i mineralnih đubriva na hemijska i biološka svojstva pseudogleja. Zbornik radova Poljoprivrednog fakulteta Beograd, 36 (596): 171-180.

Kabata-Pendias A. (2011): Trace elements in soils and plants. $4^{\text {th }}$ edition, Florida: CRC Press, Boca Ration.

KrishnaRaj S., Dan T.V., Saxena P.K. 2000. A fragrant solution to soil remediation, International Journal of Phytoremediation, 2: 117-132.

Lindsay W.L., Norvell W.A. (1978): Development of a DTPA soil test for zinc, iron, manganese and copper, Soil Science Society of America Journal, 42: 421-428.

McLaughlin M.J., Parker D.R., Clarke J.M. (1999). Metals and micronutrients-food safety issues. Field Crops Research, 60: 143-163.

Memon A.R., Aktoprakligil D., Özdemir A. Vertii A. (2001): Heavy metal accumulation and detoxification mechanisms in plants. Turkish Journal of Botany, 25: 111-121.

Pavlović R., Bošković-Rakočević LJ., Paunović A. (2014): Uticaj fosfornih đubriva na prinos i sadržaj kadmijuma u krompiru. Zbornik radova XIX Savetovanje o biotehnologiji sa međunarodnim učešćem, Agronomski fakultet u Čačku,19 (21): 123-127.

Rengel Z., Damon P.M. (2008): Crops and genotypes differ in efficiency of potassium uptake and use. Physiologia Plantarum, 133: 624-636. 
Rostami A., Davtyan V.A., Ahmadvand G. (2015): The effect of green manures and nitrogen fertilizer on yield, yield components and nitrate accumulation of potato tuber. International Journal of Biosciences, 6 (8): 140-148.

Trehan S.P., Sharma R.C. (2002): Potassium uptake efficiency of young plants of three potato cultivars as related to root and shoot parameters. Communications in Soil Science and Plant Analysis, 33: 1813-1823.

Wei B., \& Yang L. (2010). A review of heavy metal contaminations in urban soils, urban road dusts and agricultural soils from China. Microchemical Journal, 94: 99-107.

Zhuang P., McBride M.B., Xia H., Li N., Li Z. (2009). Health risk from heavy metals via consumption of food crops in the vicinity of Dabaoshan mine, South China. Science of the Total Environment, 407: 1551-1561.

Worthington V. (2001): Nutritional quality of organic versus conventional fruits, vegetables, and grains. Journal of Alternative Complement Medicine, 7 (2): 161-173. 


\title{
UTICAJ RAZLIČITE DOZE I NAČINA PRIMENE NPK-ĐUBRIVA NA KVALITET KRTOLA KROMPIRA
}

\author{
Ljiljana Bošković-Rakočević ${ }^{1}$, Zoran Dinić ${ }^{2}$, Goran Dugalić ${ }^{1}$, Marijana \\ Dugalić $^{1}$, Jelena Mladenović ${ }^{1}$, Milena Đurić ${ }^{1}$ \\ ${ }^{1}$ Univerzitet u Kragujevcu, Agronomski fakultet,Cara Dušana 34, 32000 Čačak, \\ Srbija \\ ${ }^{2}$ Institut za zemljište, Teodora Drajzera 6, 11000 Beograd, Srbija
}

\begin{abstract}
Rezime
U cilju ispitivanja uticaja različitih doza i načina primene NPK-đubriva na kvalitet krtola krompira sorte Karera izvedena su ispitivanja tokom vegetacione sezone krompira 2015. godine na zemljištu tipa luvisol, u ataru sela Bzovik (planinski masiv Radočelo, opština Kraljevo). Ogled je postavljen u sledećim varijantama: 1. T1 - Kontrola (neđubreno); 2. T2 - NPK 16:16:16 u količini 1500 $\mathrm{kg} / \mathrm{ha}$, primenjeno u brazde za vreme sadnje; 3. T3 - NPK 16:16:16 u količini $1200 \mathrm{~kg} / \mathrm{ha}$, primenjeno u brazde za vreme sadnje; 4. T4 - NPK 16:16:16 u količini $700 \mathrm{~kg} / \mathrm{ha}$ za vreme predsetvene pripreme i $500 \mathrm{~kg} / \mathrm{ha} \mathrm{u}$ brazde za vreme sadnje. Rezultati analiza hranljive vrednosti krtola krompira ukazuju da je sadržaj svih ispitivanih elemenata bio veći u kori u odnosu na srž krtole. Najveći sadržaj svih ispitivanih elemenata utvrđen je primenom najveće doze (1500 kg/ha), dok je najmanji sadržaj hraniva, osim kod $\mathrm{Fe}$, utvrđen primenom NPK-đubriva u količini $700 \mathrm{~kg} / \mathrm{ha}$ predsetveno i $500 \mathrm{~kg} / \mathrm{ha}$ u sadnji, pri čemu su sve vrednosti bile u okviru optimalnih količina.
\end{abstract}

Ključne reči: krompir, NPK đubrivo, kvalitet krtole. 